\title{
Analisis Kekuatan Struktur Atas Jalan Layang Terhadap Beban Gempa (Studi Kasus: 6 Ruas Tol Dalam Kota Jakarta Tahap 1 Seksi A)
}

\section{(Strength Analysis of Flyover Structure Based on Earthquake Spectrum Response (Case Study: 6 Routes of Jakarta Inner Toll Stage 1 Section A)}

\author{
Aini Maryam Ridwan ${ }^{*}$, Muhammad Fauzan', dan Sekar Mentari ${ }^{1}$ \\ ${ }^{1}$ Departemen Teknik Sipil dan Lingkungan, Fakultas Teknologi Pertanian, Institut Pertanian Bogor. \\ Kampus IPB Dramaga, PO BOX 220, Bogor, Jawa Barat Indonesia \\ *Penulis Korespondensi: aini_maryam27@apps.ipb.ac.id
}

Diterima: 29 September 2019

Disetujui: 26 Desember 2019

\begin{abstract}
The high potential of earthquake in Indonesia made the earthquake as an important factor in the planning of a building. The study aimed to make modelling, analyzing structure displacement during earthquake, knowing the vibration period and the stiffness of the structure and analyzing the inner force. The research was conducted in Kelapa Gading North Jakarta. The research used secondary data from KSO Jaya Konstruksi-Adhikarya. The flyover modeling was based on secondary data and used CSI bridge. The results showed structure displacement was $92.5 \mathrm{~mm}$ and it was lower than allowable displacement value, so was classified as the safe category. There were 12 vibration modes that could be occured in the flyover structure. The largest vibration period occurred in mode 1 and was equal to 0.84 sec which represented the behavior of the structure. The total stiffness value of the structure was $275512.95 \mathrm{kN} / \mathrm{m}$. The inner force of the structure were axial force, shear force, torsion and the moment.
\end{abstract}

Keywords: CSI bridge, displacement, earthquake, flyover, force.

\section{PENDAHULUAN}

Jalan tol layang dalam Kota Jakarta atau sering disebut dengan 6 ruas jalan tol dalam Kota Jakarta adalah rencana jalan tol yang akan mengadopsi konstruksi jalan layang penuh dan terintegrasi dengan transportasi umum (BRT). Jalan tol ini terdiri dari 6 ruas dan secara keseluruhan memiliki panjang $69.77 \mathrm{~km}$. Ditargetkan 6 ruas jalan tol tersebut akan dioperasikan pada tahun 2022. Enam ruas tol dalam kota ini merupakan Proyek Strategis Nasional (PSN), yang terlampir dalam Peraturan Presiden No.3 Tahun 2016 maupun dalam Peraturan Presiden (Perpres) perubahan No.58 Tahun 2017.

Indonesia merupakan negara yang berada di antara empat lempeng aktif tektonik yaitu tapal batas lempeng Eurasia, lempeng Indo-Australia, lempeng Filipina dan lempeng Pasifik (Irsyam 2005).
Berdasarkan kondisi tersebut, untuk perencanaan struktur tahan gempa di Indonesia diperlukan analisis berdasarkan peraturan, pedoman dan standar yang telah dikeluarkan oleh pemerintah. Estimasi resiko gempa memerlukan suatu kurun waktu kejadian gempa independen dalam rentang magnitude tertentu yang lengkap dalam suatu katalog gempa (Hutapea dan Mangape 2009).

Gempa bumi dapat dikategorikan dalam dua jenis yaitu gempa vulkanik dan gempa tektonik. Gempa vulkanik terjadi akibat aktivitas gunung berapi yang memuntahkan lahar panas dari perut gunung berapi. Gempa tektonik terjadi karena adanya pergerakan lempeng kerak bumi (Tavio dan Wijaya 2018). Menurut Sanjaya (2014) gempa adalah suatu gejala fisik yang ditandai dengan bergetarnya bumi dengan berbagai intensitas. Menurut Nur (2010) penyebab gempa bumi dapat 
berupa dinamika bumi (tektonik), aktivitas gunung api, akibat meteor jatuh, longsoran (di bawah muka air laut), maupun ledakan bom nuklir di bawah permukaan. Beban gempa adalah salah satu beban yang harus diperhitungkan dalam mendesain suatu bangunan di daerah yang rawan gempa. Tidak seperti beban-beban tipe lainnya yang besarnya tidak dipengaruhi oleh struktur bangunan yang terkena gempa, besarnya beban gempa sangat dipengaruhi oleh kondisi struktur bangunannya. Terjadinya gempa menghasilkan energi yang kuat yang menjalar di permukaan bumi dengan gelombang vertikal dan horizontal (Wulandari 2013).

Tingginya potensi gempa di Indonesia menjadikan gempa sebagai salah satu faktor penting dalam perencanaan suatu bangunan. Jika struktur jalan layang ini tidak mampu menahan gempa, maka akan menimbulkan dampak yang besar bagi kawasan-kawasan yang dilewatinya. Tujuan penelitian ini adalah membuat pemodelan, menganalisis displacement struktur selama gempa, menentukan periode getar dan kekakuan dari struktur serta menganalisis gaya dalam.

\section{METODOLOGI}

Penelitian dilaksanakan dari bulan Februari sampai bulan September 2019. Pengolahan, pemodelan struktur, perhitungan analisis data dan penyusunan skripsi dilakukan di Departemen Teknik Sipil dan Lingkungan. Lokasi proyek konstruksi 6 ruas tol dalam Kota Jakarta terletak di Jalan Pegangsaan dua Nomor 33 Jakarta Utara. Peta lokasi penelitian disajikan pada Gambar 1.

Alat yang digunakan dalam penelitian ini adalah laptop ASUS core i3 yang dilengkapi dengan program AutoCAD 2016, Program Ms. Word, Program Ms. Excel, Program CSI Bridge versi 2016. Bahan penelitian merupakan data sekunder berupa gambar perencanaan dan kriteria desain yang diperoleh dari proyek pembangunan 6 ruas jalan tol dalam Kota Jakarta Tahap 1 Seksi A, serta Peta Hazard Gempa Indonesia.

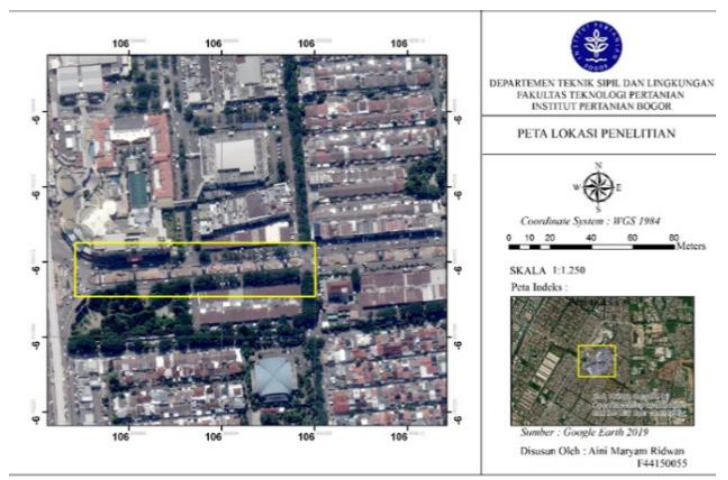

Gambar 1 Lokasi objek penelitian

Peraturan - peraturan yang berkaitan dengan penelitian ini adalah SNI 1725:2016 tentang pembebanan untuk jembatan, dan SNI 1726:2012 tentang tata cara perencanaan ketahanan gempa untuk struktur bangunan gedung dan non gedung.

Analisis struktur atas 6 ruas tol dalam Kota Jakarta terhadap beban gempa dilakukan dengan empat tahap. Penelitian dimulai dengan studi pustaka guna mencari informasi yang terkait dengan penelitian, mengumpulkan data sekunder berupa data teknis dari objek penelitian. Kemudian dilakukan pengolahan data yang meliputi kegiatan permodelan dengan menggunakn software CSI Bridge versi 2016 dan berdasarkan data yang diperoleh dari kontraktor 6 ruas tol dalam Kota Jakarta yaitu KSO PT Jaya Konstruksi - Adhikarya yang berupa shop drawing (SD) serta perhitungan manual.

Untuk perhitungan pembebanan jembatan, maka beban yang diperhitungkan adalah beban mati, beban hidup, dan beban gempa. Beban mati terdiri dari struktur jembatan itu sendiri dan beban mati tambahan. Beban hidup berupa beban lalu lintas yang terdiri dari beban lajur "D" dan beban truk "T".

Pembebanan ini harus sesuai dengan SNI 1725:2016. Beban gempa yang 
dipakai dalam penelitian ini berupa respon spektrum yang diperoleh dan didesain menggunakan parameter yang telah diatur dalam SNI 1726:2012. Parameter yang dibutuhkan untuk mendesain respon spektra adalah penentuan kelas situs tanah pada daerah struktur jembatan berada, Grafik respon spektra dimasukkan ke dalam program CSI Bridge sebagai respon spectrum function, serta tahapan akhir berupa analisis data. Data berupa nilai tegangan gelagar, gaya dalam, dan displacement pada jembatan dievaluasi dan dibandingkan dengan nilai izin yang ada. Apabila berada di bawah nilai izin, maka konstruksi dianggap aman. Sebaliknya, apabila ada salah satu parameter yang melebihi nilai izin yang telah ditentukan, dapat disimpulkan bahwa konstruksi tidak aman (Paradita 2018)

\section{HASIL DAN PEMBAHASAN}

\section{Pemodelan Jembatan}

CSI Bridge adalah analisis khusus dan software desain untuk rekayasa konstruksi sistem jembatan yang dikeluarkan oleh perusahaan Computer and Structure Inc untuk memodelkan jembatan (Meidiansyah et al. 2016). Pembuatan model jembatan dilakukan dengan menggunakan aplikasi CSI Bridge versi 2016 berdasarkan gambar teknik dan data proyek yang diperoleh dari KSO Jaya Konstruksi-Adhikarya. Pembangunan 6 (enam) Ruas Jalan Toll dalam Kota Jakarta Tahap 1 Ruas Semanan-Sunter dan Sunter-Pulo Gebang Seksi A Kelapa Gading- Pulo Gebang (STA. 21+881 - STA. 31+168) ini memiliki panjang lintasan $9.8 \mathrm{~km}$. Pada penelitian ini dilakukan pemodelan sebanyak 5 span (P.8.41-P.8.46) dengan expansion joint (EJ.9-EJ.10) sebagai pembatasnya. Hasil dari pemodelan ditunjukkan seperti pada Gambar 2. Data general:

1. Tipe jalan layang merupakan precast segmental box girder
2. Superstruktur menggunakan box girder dengan kekuatan K500

3. Substruktur berupa pierhead dan pier dengan kekuatan K350

4. Bearing system menggunkan lead rubber bearing

5. Jalan dengan 2 Jalur dengan masingmasing jalur memiliki 3 lajur $(3,25 \mathrm{~m})$ dan bahu jalan (2,5 m).

6. Lebar total jembatan $26,2 \mathrm{~m}$

7. Panjang total $196,25 \mathrm{~m}$

8. Panjang per span:

i. $\quad$ P.8.41-P. $8.42=45 \mathrm{~m}$

ii. P.8.42-P. $8.43=45 \mathrm{~m}$

iii. P.8.43-P. $8.44=45 \mathrm{~m}$

iv. P.8.44-P.8.45 = 30,625 m

v. P.8.45-P.8.46 $=30,625 \mathrm{~m}$

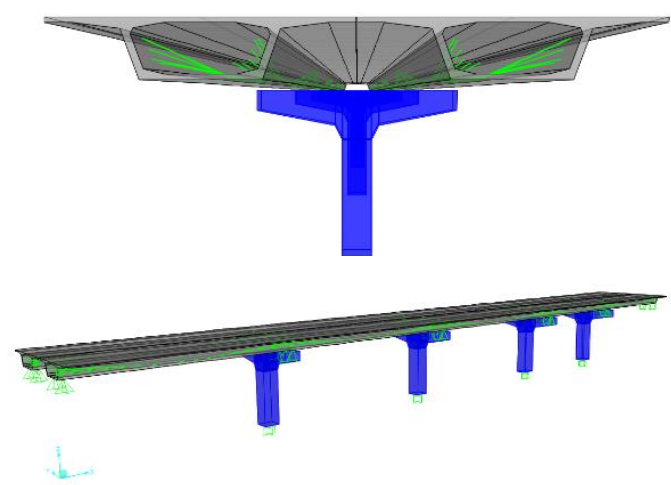

Gambar 2 Hasil pemodelan jembatan

\section{Dimensi Box Girder}

Terdapat 3 jenis box girder yang digunakan pada jembatan ini yaitu tipe EJ, SV, dan DV. EJ merupakan box girder yang ditempatkan di ujung span sebagai tempat dilakukannya stressing tendon. DV merupakan deviator box dimana tendon akan berada di bagian bawah dalam box. SV merupakan box girder tipikal. Perbedaan ketiga box girder terletak pada feature tambahan dan panjang segmennya, sehingga pemodelan dilakukan dengan menggunakan 1 tipe box girder. Gambar 3 merupakan penampang box girder. 


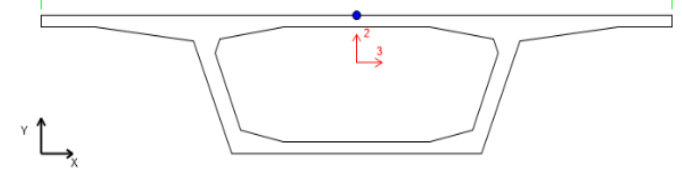

Gambar 3 Penampang Box Girder

\section{Dimensi Pier dan Pierhead}

Pier dan pierhead dimodelkan seperti pada Gambar 4. Dengan ketinggian total pier sebesar $17 \mathrm{~m}$. Pada setiap pier akan dipasang LRB sebagai penyambung antara pier dengan box girder. Pada setiap pier akan ditempatkan 4 box girder dengan 2 LRB untuk masing-masing box girder.

\section{Material Properties}

Pier dan pierhead menggunakan beton dengan mutu K-400 atau setara dengan 34 Mpa. Sementara untuk box girder menggunakan beton K-500 atau setara dengan $42 \mathrm{Mpa}$. Berikut properties beton berdasarkan silinder tes;

Kuat tekan silinder, fc': $42 \mathrm{MPa}$

Modulus elastisitas, E :30,500 MPa

Berat jenis, $\gamma \quad: 25 \mathrm{kN} / \mathrm{m}^{3}$

Poisson ratio, $v \quad: 0.2$

Koefisien muai, $\alpha \quad: 1.1 \times 10^{-5} /{ }^{\circ} \mathrm{C}$

Kuat tekan silinder, fc': $34 \mathrm{MPa}$

Modulus elastisitas, E : 27,500 Mpa

Berat jenis, $\gamma \quad: 25 \mathrm{kN} / \mathrm{m}^{3}$

Poisson ratio, $v \quad: 0.2$

Koefisien muai, $\alpha \quad: 1.1 \times 10^{-5} /{ }^{\circ} \mathrm{C}$

\section{Tendon}

Struktur box girder bersifat segmental dan berongga, maka diperlukan tendon untuk menghubungkan satu dengan yang lain sekaligus berfungsi sebagai tulangan dalam menahan beban seperti pada konstruksi pada umumnya. Terdapat dua tipe tendon yang digunakan berdasarkan jumlah strandsnya yaitu 12 strand dan 19 strand.

Karakteristik material yang digunakan adalah:
Spesifikasi :ASTM A416 Grade 270

Tipe : 7 wires low relaxation steel

Diameter nominal : $12.7 \mathrm{~mm}(0.5 ")$

Luas nominal : $98.7 \mathrm{~mm} 2$

Massa nominal : $0.775 \mathrm{~kg} / \mathrm{m}$

Modulus elastisitas, E : $195000 \mathrm{MPa}$

Kuat tarik ultimit, fpu: $1860 \mathrm{MPa}$

Kuat tarik leleh, fpy : 1670 Mpa

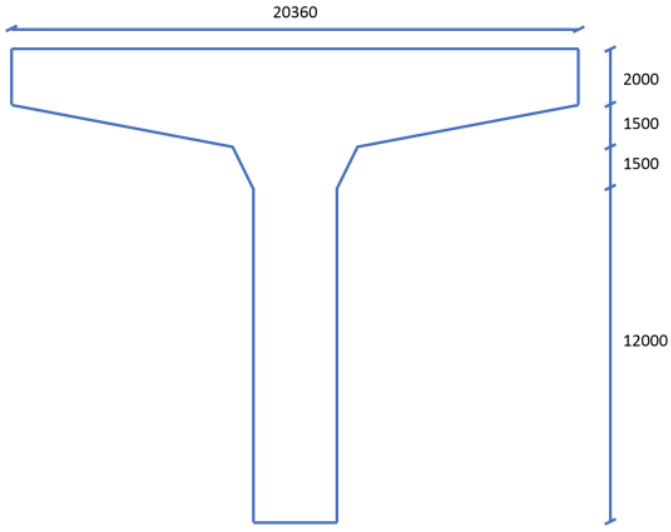

Gambar 4 Dimensi pier (mm)

\section{Lead Rubber Bearing}

Struktur jembatan merupakan struktur menerus dari P8.41 hingga P8.46. Box girder dan pier merupakan struktur yang terpisah sehingga diperlukan struktur penghubung. Struktur penghubung antara box girder dan pier pada model ini adalah lead rubber bearing (LRB). Digunakan 2 LRB untuk setiap box girder, sehingga terdapat 8 LRB untuk setiap pierhead. Karakteristik LRB yang digunakan adalah : Rubber width: $550 \mathrm{~mm}$

Rubber length: $550 \mathrm{~mm}$

Total thickness: $125.24 \mathrm{~mm}$

Non seismic vertical load: $5500 \mathrm{kN}$

Max/min seismic vertical load: 2400 / $5500 \mathrm{kN}$

Berdasarkan data yang didapatkan, diketahui nilai Keff pada saat seismic test $1 \%$ sebesar $59.1 \mathrm{kN} / \mathrm{mm}$ dengan damping sebesar $26.35 \%$. Data tersebut digunakan sebagai input dari karakteristik rubber isolator pada Csi Bridge.

\section{Input Pembebanan}

Umur rencana jembatan ditentukan 50 tahun, sehingga dikategorikan sebagai 
jembatan biasa sesuai dengan SNI 1725:2016. Besarnya pembebanan yang terjadi dapat dijabarkan dalam contoh perhitungan:

\section{Beban Mati}

1. Girder $=\mathrm{Ag} \times \mathrm{W}_{\mathrm{c}} \times \mathrm{L}$ $=6.7 \mathrm{~m}^{2} \times 25 \mathrm{kN} / \mathrm{m}^{3} \times 196.25 \mathrm{~m}$ $=33218.9 \mathrm{kN}$

2. Pier $=A g \times W_{c} \times L$ $=111.865 \mathrm{~m}^{2} \times 25 \mathrm{kN} / \mathrm{m}^{3} \times 3.5 \mathrm{~m}$ $=9788.188 \mathrm{kN}$

3. Tendon $=($ Jumlah tendon $\mathrm{x}$ Jumlah strand $\mathrm{x}$ berat 1 strand $\mathrm{x}$ panjang)

$=(12 \times 19 \times 0.0965 \times 135)+(12 \times 12 \times$ $0.0965 \times 61.25)$ $=3222.129 \mathrm{kN}$

4. Parapet $=\mathrm{Ag} \times \mathrm{W}_{\mathrm{c}} \times \mathrm{L}$ $=0.48 \mathrm{~m}^{2} \times 25 \mathrm{kN} / \mathrm{m}^{3} \times 196.5$ $=2355 \mathrm{kN}$

\section{Beban Lajur D}

1. Beban tersebar merata (BTR)

Beban tersebar merata memiliki intensitas $q$ yang nilainya bergantung pada panjang bentangnya. Beban diinput sebagai beban area pada aplikasi CSI Bridge.

Untuk bentang dengan panjang $45 \mathrm{~m}$ $q=9.0 \times\left(0.5+\frac{15}{45}\right) k P a=7.5 \mathrm{kN} / \mathrm{m}^{2}$

Untuk bentang dengan panjang 30.625 $\mathrm{m}$

$$
\begin{array}{r}
q=9.0 \times\left(0,5+\frac{15}{30.625}\right) k P a \\
=8.91 \mathrm{kN} / \mathrm{m}^{2}
\end{array}
$$

2. Beban Garis (BGT)

Beban garis memiliki intensitas (p) 49.0 $\mathrm{kN} / \mathrm{m}$ dan ditempatkan tegak lurus arah lalu lintas pada jembatan. Beban diinput dalam bentuk beban terpusat dalam aplikasi CSI Bridge. Untuk bentang di bawah $50 \mathrm{~m}$. Faktor beban dinamis diambil sebesar $40 \%$, sehingga beban harus dinaikkan sebesar $40 \%$.

$p=49 \times$ lebar $x F B D=49 \times 9.75 \times 1.4$

$$
=668.85 \mathrm{kN}
$$

\section{Beban Truk}

Beban truk yang digunakan sesuai dengan SNI 1725-2016 yaitu truk dengan berat 50 ton $=500 \mathrm{kN}$. Berat dari masingmasing as disebarkan menjadi 2 beban merata sama besar, dan jarak antara 2 as berada di antara 4-9 $\mathrm{m}$ dengan lebar as sebesar $1.75 \mathrm{~m}$.

\section{Gaya Rem}

Gaya rem bekerja dalam arah horisontal sumbu jembatan. Besarnya gaya rem yaitu 5\% dari beban lajur D yang dianggap ada pada semua jalur lalulintas. Gaya rem yang nilainya akan diinputkan ke dalam program dihitung sebagai berikut: Gaya rem total = beban lajur "D" $\mathrm{x}$ lebar lajur x panjang jembatan x $5 \%$

$=7.5 \mathrm{kN} / \mathrm{m}^{2} \times 3.25 \mathrm{~m} \times 196.25 \mathrm{~m} \times 5 \%$ $=239.18 \mathrm{kN}$

Gaya rem per kolom = gaya rem total $x 6$ lajur 14 kolom

$=249.375 \times 6 / 4=358.77 \mathrm{kN}$

\section{Beban Tumbukan}

Gaya tumbukan yang bekerja sebesar $1000 \mathrm{kN}$ searah horizontal dengan sudut $10^{\circ}$, gaya ditempatkan $1800 \mathrm{~mm}$ di atas permukaan jalan. Gaya tersebut kemudian diubah ke arah x dan y (Gambar 5).

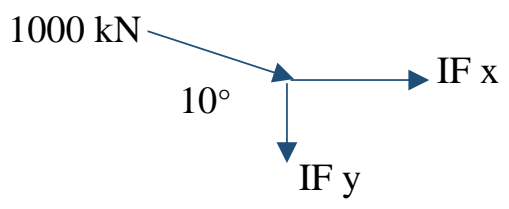

Gambar 5 Arah gaya tumbukan

$$
\begin{array}{ll}
\mathrm{F} & =1000 \mathrm{kN} \\
\mathrm{Fx} & =\operatorname{Cos} 10^{\circ} 1000 \mathrm{kN}=984.808 \mathrm{kN} \\
\mathrm{Fy} & =\operatorname{Sin} 10^{\circ} 1000 \mathrm{kN}=173.648 \mathrm{kN}
\end{array}
$$

\section{Respon Spektrum Gempa}

Pembebanan akibat gaya gempa, respons dan pembebanannya berubah menurut waktu sehingga dalam perhitungannya gaya gempa tidak mempunyai solusi tunggal seperti pada gaya statis (Indra et.al 2016). Percepatan 
gempa di muka tanah adalah parameter gempa yang memberikan dampak langsung pada struktur. Percepatan gempa bersifat dinamik, begitu juga dengan respon struktur yang ditimbulkan (Anggen et al 2014).

Percepatan puncak muka tanah dan spektrum respons di permukaan tanah, dipengaruhi oleh beberapa faktor seperti jenis tanah, sumber gempa bumi sebagai input motion, nilai percepatan puncak batuan dasar, asumsi-asumsi yang digunakan dalam perhitungan matematis, serta metoda yang digunakan (Sukanta dan Prakoso 2010).

Respon spektrum adalah suatu spektrum yang disajikan dalam bentuk grafik/plot antara periode getar struktur, lawan respon-respon maksimum berdasarkan rasio redaman dan gempa tertentu. Respon-respon maksimum dapat berupa simpangan maksimum (spectrum displacement, SD) kecepatan maksimum (spectrum velocity, SV) atau percepatan maksimum (spectrum acceleration, SA) massa struktur single degree of freedom (SDOF) (Roring et.al 2016).

Respon spektrum diperoleh dari respon spektra puskim yang mengacu pada peta zonasi gempa 2010 dan didesain berdasarkan SNI 1726:2012. Jalan layang yang ditinjau pada penelitian ini berada di Kelapa Gading, dengan nilai $\mathrm{S}_{\mathrm{S}}=0.656 \mathrm{~g}$, $\mathrm{S}_{1}=0.289 \mathrm{~g}$, dan PGA $=0.349 \mathrm{~g}$ yang ditentukan berdasarkan peta zonasi gempa SNI 1726:2012. Selanjutnya dilakukan perhitungan parameter-parameter yang digunakan untuk membangun respon spektra.

Berdasarkan nilai Ss dan kelas situs tanah dapat ditentukan nilai $\mathrm{Fa}$, diperoleh nilai $\mathrm{Fa}=1.275$. Nilai $\mathrm{Fv}$ ditentukan berdasarkan nilai $\mathrm{S} 1$ dan kelas situs tanah berdasarkan tabel yang tertera dalam SNI dengan interpolasi linear dan diperoleh $\mathrm{Fv}=1.822$.
Parameter respon spektrum percepatan pada periode 0.2 detik $\left(\mathrm{SM}_{\mathrm{S}}\right)$ dan periode 1 detik $\left(\mathrm{SM}_{1}\right)$ sebesar:

$$
\begin{aligned}
& \mathrm{SM}_{\mathrm{S}}=\mathrm{Fa} \times \mathrm{S}_{\mathrm{S}}=1.275 \times 0.656=0.8365 \\
& \mathrm{SM}_{1}=\mathrm{Fv} \times \mathrm{S}_{1}=1.822 \times 0.289=0.5265
\end{aligned}
$$

Parameter percepatan spektra desain untuk periode 0.2 (SDS) dan periode 1 detik (SD1) sebesar:

$$
\begin{aligned}
& \mathrm{SD}_{\mathrm{S}}=2 / 3 \mathrm{SM}_{\mathrm{S}}=2 / 3 \times 0.8365=0.5576 \\
& \mathrm{SD}_{1}=2 / 3 \mathrm{SM}_{1}=2 / 3 \times 0.5265=0.3510 \\
& \text { Periode fundamental struktur }\left(\mathrm{T}_{\mathrm{S}}\right) \\
& \text { sebesar } 0.629 \text { detik }
\end{aligned}
$$

\section{Periode Getar dan Kekakuan Struktur}

Pembebanan pada suatu struktur dapat menyebabkan terjadiya getaran pada struktur. Mode getar didefinisikan sebagai ragam/pola struktur yang terjadi ketika sedang menerima beban dinamik dan berhubungan dengan periode yang dihasilkan suatu getaran. Periode struktur memberikan pengaruh terhadap besarnya kekakuan struktur. Semakin besar periode maka semakin kecil kekakuan strukturnya. Berdasarkan hasil analisis didapatkan 12 mode getar yang mungkin terjadi pada struktur dan ditunjukkan pada Gambar 6 . Periode untuk masing-masing mode seperti pada Tabel 1 .

Tabel 1 Nilai Periode Struktur

\begin{tabular}{cr}
\hline No. Mode & Periode (det) \\
\hline 1 & 0.84198 \\
2 & 0.51915 \\
3 & 0.43315 \\
4 & 0.42493 \\
5 & 0.41346 \\
6 & 0.41029 \\
7 & 0.40371 \\
8 & 0.39252 \\
9 & 0.38525 \\
10 & 0.35297 \\
11 & 0.34875 \\
12 & 0.34868 \\
\hline
\end{tabular}




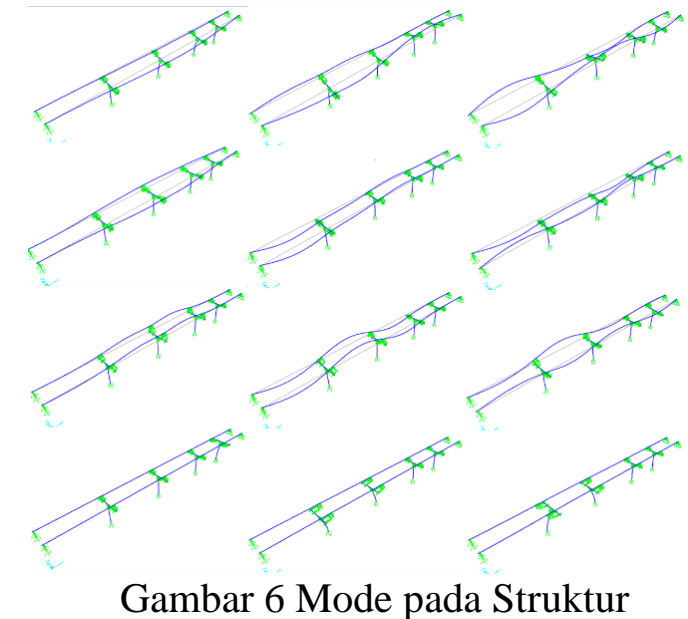

Setiap mode getar memiliki nilai periode yang berbeda. Berdasarkan Gambar 5, diperoleh nilai periode yang mewakili keseluruhan perilaku struktur jembatan yaitu sebesar 0.84198 det. Struktur dapat dikategorikan sebagai struktur fleksibel karena memiliki nilai periode di atas periode respon spektrum.

Kekakuan dapat diartikan sebagai gaya per satuan deformasi, atau dengan kata lain, gaya yang diperlukan untuk menahan satu satuan deformasi. Berdasarkan nilai periode dapat dihitung nilai kekakuan struktur.

$$
\begin{aligned}
\frac{2 \pi}{T}= & \sqrt{\frac{K \cdot g}{w}} \\
K_{\text {total }} & =\left(\frac{2 \pi}{T}\right)^{2} \times \frac{W}{g} \\
& =\left(\frac{2 \pi}{0.84198}\right)^{2} \times \frac{48584.23}{9.81} \\
& =275512.9483 \mathrm{kN} / \mathrm{m}
\end{aligned}
$$

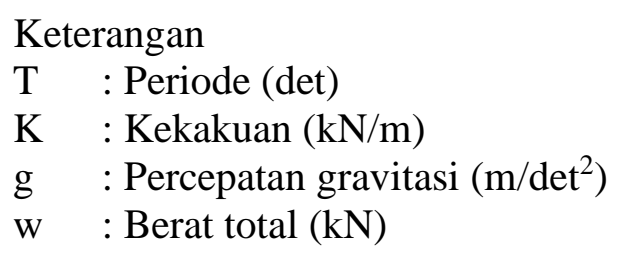

Berdasarkan perhitungan didapatkan nilai kekakuan total struktur sebesar $275512,9483 \mathrm{kN} / \mathrm{m}$. Besarnya kekakuan mempengaruhi besarnya deformasi yang terjadi pada struktur. Periode getar mempengaruhi besarnya kekakuan, dan semakin besar periode maka semakin kecil kekakuan yang terjadi. Kekakuan maksimum yang dapat terjadi pada struktur yaitu pada saat percepatan maksimum sebesar 0,842 det. Nilai kekakuan struktur pada jalan layang ini sangat dipengaruhi oleh kekakuan effektif dari LRB yang digunakan. Semakin kecil nilai kekakuan LRB maka struktur semakin fleksibel, semakin besar nilai kekakuan LRB maka struktur akan menjadi semakin kaku.

\section{Analisis Displacement}

Displacement merupakan perpindahan suatu objek terhadap posisi awalnya. Displacement ditinjau baik dari arah $\mathrm{x}, \mathrm{y}$, dan $\mathrm{z}$ dengan mengambil nilai terbesar untuk masing-masing arah. Batas displacement bentang jembatan adalah $\Delta \leq$ L/800 (Kristin et.al 2018). Panjang bentang jembatan adalah 196,25 m, maka displacement yang diijinkan tidak lebih dari $245,3 \mathrm{~mm}$.

Gambar 7 menunjukkan besarnya displacement yang terjadi pada struktur. Displacement yang terjadi pada kombinasi beban layan arah $\mathrm{z}$ terbesar adalah $-86,8$ mm, sedangkan pada arah $\mathrm{x}$ dan y sebesar $9,08 \mathrm{~mm}$ dan $-0,978 \mathrm{~mm}$. Besarnya displacement yang terjadi di bawah nilai displacement izin yaitu 245,3 mm. Maka, dapat dikatakan bahwa jembatan ini aman.

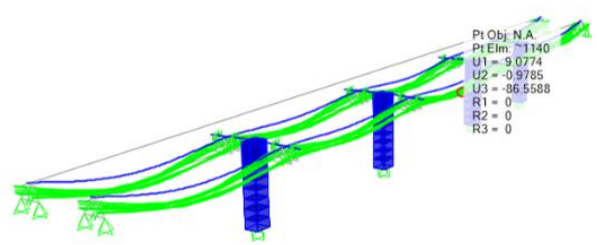

Gambar 7 Displacement pada Struktur

\section{Gaya Dalam Struktur}

Gambar 8 menunjukkan gaya dalam momen akibat beban sendiri yang dihasilkan dari analisis menggunakan program CSI Bridge. Kemudian dilakukan 
perhitungan momen girder secara manual untuk membandingkannya dengan momen dari hasil program. Perbandingan dilakukan untuk mengetahui kesesuaian momen yang dihasilkan.

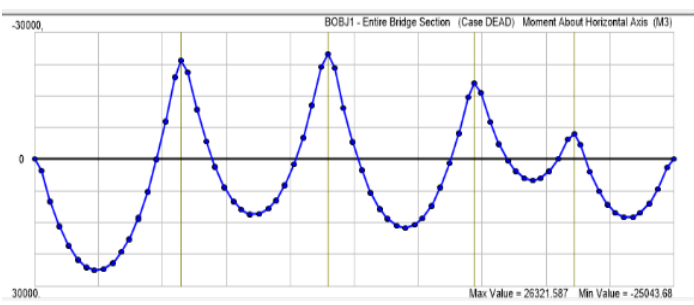

Gambar 8 Gaya dalam akibat beban sendiri

$$
\begin{aligned}
M \text { manual } & =\frac{1}{8} \text { q girder } x L^{2} \\
& =\frac{1}{8}(\operatorname{Ag} \times W c) \times L^{2} \\
& =\frac{1}{8}(6.77 \times 25) \times 45^{2} \\
& =42846.045 \mathrm{kNm} \\
\text { M program } & =\text { Mmax }+ \text { Mmin } \\
& =26321.58+25043.68 \\
& =51365.27 \mathrm{kNm} \\
\text { M program } & \approx \text { M manual }
\end{aligned}
$$

M program dan $\mathrm{M}$ manual memiliki nilai yang sedikit berbeda dan ini dapat disebabkan panjang span yang berbedabeda. Selain itu, perbedaan dapat terjadi karena analisis menggunakan metode perhitungan yang berbeda (Deshariyanto 2015).

Gaya aksial merupakan gaya dalam yang bekerja tegak lurus searah penampang dan titik pusat kerja gaya pada titik berat dimana gaya itu bekerja. Gaya aksial pada jembatan disebabkan oleh prestress tendon, gaya rem, reaksi perletakan dan beban gempa. Gaya aksial maksimum yang dihasilkan oleh kombinasi beban SLS sebesar -2204.38 kN, nilai (-) menunjukkan arah gaya aksial menuju sumbu batang sedangkan nilai $(+)$ menunjukkan arah gaya aksial keluar dari sumbu batang.

Gaya geser merupakan gaya dalam yang bekerja sejajar penampang melintang elemen struktur dimana gaya itu bekerja.
Gaya geser yang terjadi disebabkan oleh beban mati, reaksi perletakan, dan beban gempa. Gaya geser maksimum dihasilkan oleh kombinasi beban SLS sebesar +7532.4212 kN. Nilai (+) menunjukkan terjadi pergeseran ke atas pada sisi bawah sedangkan nilai (-) menunjukkan terjadi pergeseran kebawah pada sisi atas.

Torsi adalah momen puntir yang bekerja di sepanjang batang yang mengakibatkan terpilinnya elemen struktur dalam arah longitudinal. Torsi dapat terjadi karena bekerjanya beban transveral yang tidak segaris dengan posisi garis berat penampang. Torsi maksimum yang dihasilkan oleh kombinasi beban layan (SLS) sebesar -147.8095 kNm. Nilai torsi bernilai (-) ketika momen berputar searah jarum jam sedangkan nilai bernilai $(+)$ saat torsi berputar berlawanan arah jarum jam.

Momen merupakan perkalian seluruh gaya yang bekerja tegak lurus terhadap pusat momen dengan jaraknya. Momen lentur maksimum yang dihasilkan dari kombinasi beban SLS sebesar +50801.53 $\mathrm{kNm}$. Nilai negatif menunjukkan elemen struktur mengalami lentur ke atas yang artinya sisi atas tertarik dan sisi bawah tertekan. Nilai positif menunjukkan elemen struktur melengkung ke bawah yang artinya sisi atas tertekan dan sisi bawah tertarik.

Gaya aksial maksimum yang dihasilkan kombinasi ULS sebesar -342.57 $\mathrm{kN}$. Gaya geser maksimum kombinasi beban ULS sebesar $+11348.646 \mathrm{kN}$. Torsi yang dihasilkan oleh kombinasi beban ULS sebesar -234.8682 kNm. Nilai momen lentur yang dihasilkan program untuk kombinasi beban ULS sebesar +77137.54 $\mathrm{kNm}$. Nilai gaya-gaya dalam akibat kombinasi ULS lebih besar dibandingkan kombinasi SLS, dikarenakan kombinasi ULS dikalikan dengan faktor pembebanan. 


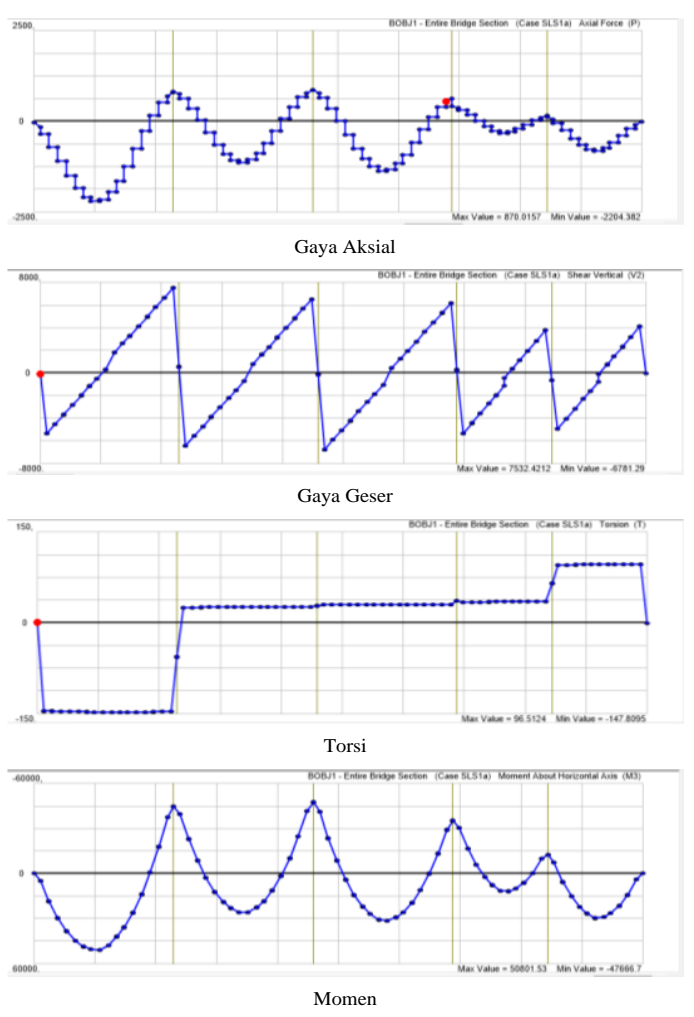

Gambar 9 Gaya dalam akibat kombinasi beban SLS

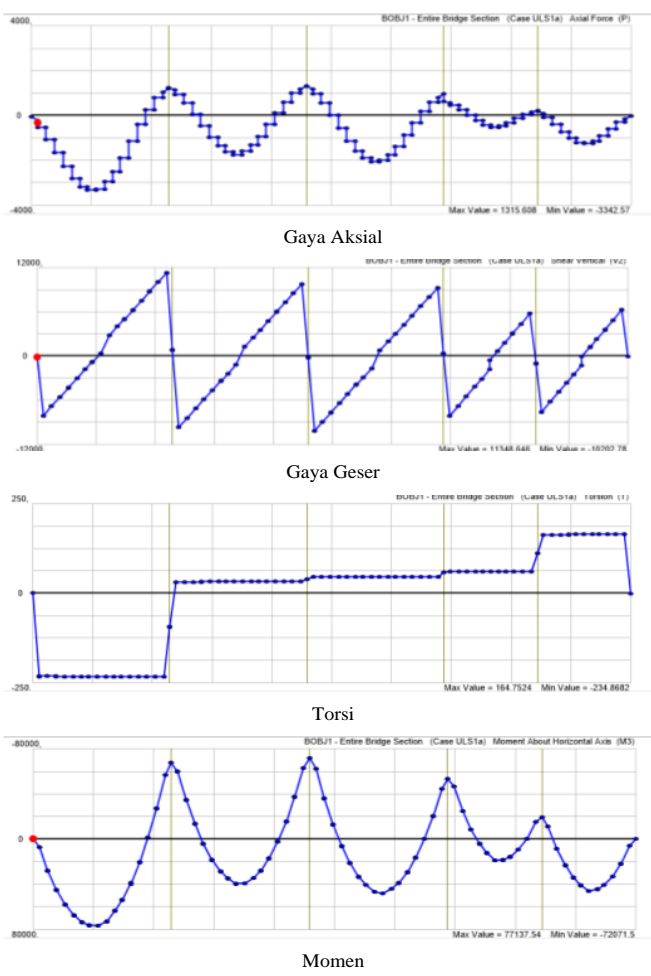

Gambar 10 Gaya dalam akibat kombinasi beban ULS

\section{KESIMPULAN}

Simpulan yang dapat ditarik dari penelitian ini adalah:

1. Pemodelan jalan layang didesain dari P.8.41 hingga P.8.46 berdasarkan data dan shop drawing yang diperoleh dari KSO Jaya Konstruksi-Adhi Karya.

2. Terdapat 12 mode getar yang mungkin terjadi pada struktur jembatan. Dengan periode terbesar terjadi pada mode 1 yaitu sebesar 0.84 det yang mewakili prilaku struktur sehingga nilai kekakuan total strukturnya sebesar $275512.95 \mathrm{kN} / \mathrm{m}$.

3. Displacement yang terjadi pada struktur sebesar $92.5 \mathrm{~mm}$ dan masih di bawah nilai displacement izinnya sehingga termasuk kategori aman.

4. Gaya dalam yang terjadi pada struktur berupa gaya aksial, gaya geser, torsi dan momen dengan nilai maksimum untuk kombinasi beban SLS masingmasing sebesar $-2204.38 \mathrm{kN} ;+7532.42$ $\mathrm{kN}$; $-147.81 \mathrm{kNm}$; $+50801.53 \mathrm{kNm}$. Sementara untuk kombinasi beban ULS masing-masing sebesar -3342.57 $\mathrm{kN} ; \quad+11348.646 \mathrm{kN} ; \quad-234.8682$ $\mathrm{kNm} ;+77137.54 \mathrm{kNm}$.

\section{DAFTAR PUSTAKA}

Anggen WS, Budi AS, Gunawan P. 2014. Evaluasi Kinerja Struktur Gedung Beritngkat Dengan Analisis Dinamik Time History Menggunakan Etabs (Studi Kasus: Hotel Di Daerah Karanganyar). E-Journal Matriks Teknik Sipil. 3(1): 313-320.

[BSN] Badan Standardisasi Nasional. 2012. Perencanaan Ketahanan Gempa. SNI 03-1726-2012. Jakarta (ID): BSN.

[BSN] Badan Standardisasi Nasional. 2016. Pembebanan untuk Jembatan. SNI 1725:2016. Jakarta (ID): BSN. 
Deshariyanto D. 2015. Perbandingan Gaya Dalam Metode Manual Dan Program. Jurnal Media Informasi Teknik Sipil UNIJA. Vol 3(1): 39-44.

Hutapea BM, Mangape I. 2009. Analisis Hazard Gempa dan Usulan Ground Motion pada Batuan Dasar untuk Kota Jakarta. Jurnal Teknik Sipil. 16(3):121131.

Indra AV, Suryanita R, Ismeddiyanto. 2016. Analisis Respons Dinamik Jembatan Rangka Baja Menggunakan Sistem Seismic Isolation Lead Rubber Bearing (LRB). Jom FTEKNIK. 3(1): 112.

Irsyam M. 2005. Pengantar Rekayasa Gempa. Bandung (ID): Institut Teknologi Bandung.

Kristin NV, Wibowo A, Setyowulan D, Wahyuni ES. 2018. Pengaruh Gempa Terhadap Perilaku Jembatan Cable Stayed Tengku Fisabililah Riau Dengan Time History Analysis. Rekayasa Sipil. Vol 12(2): 142-148.

Meidiansyah AF, Purwanto MPJ, Fauzan M. 2016. Analisis Struktur Box Girder Jembatan Fly Over Rawa Buaya Sisi Barat Terhadap Gempa. Jurnal Teknik Sipil dan Lingkungan. 1(1): 11-18.

Nur AM. 2010. Gempa Bumi, Tsunami, dan Mitigasinya. Jurnal Geografi. 7(2): 66-73.

Paradita RA. 2018. Analisis Kinerja Struktur Atas Tol Bogor Outer Ring Road Seksi 2-B Terhadap Beban Gempa [Skripsi]. Bogor (ID): Institut Pertanian Bogor.

Roring Y, Sumajouw MDJ, Dapas SO. 2016. Respon Dinamis Struktur Bangunan Beton Bertulang Bertingkat Banyak Dengan Kolom Berbentuk Pipih. Jurnal Sipil Statik.Vol 4(10): 649-655.

Sanjaya SSR. 2014. Perencanaan Struktur Gedung Asrama Mahasiswa Universitas Sriwijaya Palembang dengan Penahan Lateral Kombinasi Sistem Rangka 34 Pemikul Momen dan Dinding Struktural.
Jurnal Teknik Sipil dan Lingkungan 2:139-145.

Sukanta IN, Prakoso WA. 2010. Analisis Pengaruh Variabilitas Tanah Pada Variabilitas Spektrum Respon Gempabumi. Jurnal Meteorologi dan Geofisika. 11(2): 154-162.

Tavio, Wijaya U. 2018. Desain Rekayasa Gempa Berbasis Kinerja. Yogyakarta (ID): Andi Offset.

Wulandari S. 2013. Analisis Dan Evaluasi Struktur Atas Tower C Grand Center Point Apartment Terhadap Beban Gempa Berdasarkan Peta Gempa Indonesia 2010 [Skripsi]. Bogor (ID): Institut Pertanian Bogor. 